\title{
THE EVOLUTION OF HYBRID WARFARE. CASE STUDY - THE CONFLICT IN UKRAINE.
}

\author{
Colonel Constantin POPA ${ }^{101}$
}

\begin{abstract}
A briefforay into history shows us that hybrid warfare has been present since ancient times, through various forms of expression, in conflicts between states. Therefore, "hybrid warfare" is developing in multiple areas, being increasingly adopted at the level of some states that base their military doctrines or security strategies on methods and tools unconventional or unusual in the classical sense of war. So, hybrid warfare can be seen as a complex, integrated representation of classical warfare. But is such an approach a correct one?
\end{abstract}

Keywords: hybrid warfare, Ukraine, Russian Federation, Crimean Peninsula, NATO.

Hybrid warfare can be seen as a complex, integrated representation of classical warfare. But is such an approach, a correct one?

The explanatory dictionary of the Romanian language provides, for the term "war" - "...(Lasting) armed conflict between two or more states, nations, human groups, for the realization of economic and political interests...".

The dictionary also includes the phrase "total war", which means "armed struggle in which the aggressor state uses all means of destruction, not only against the armed forces, but also against the entire population."

It is noted that the definition of the word "war" is strictly related to the term "armed".

For the term "hybrid" the explanation in the dictionary resides in "1. (About plants and animals) - Derived from the natural or artificial crossing, sexual or vegetative of two individuals of different species, varieties, races; 2. (About ideas, facts) Made up of inappropriate, disparate elements; without harmony".

The phrase "hybrid war" has not yet been enshrined in the explanatory dictionary. Moreover, the meaning in which that phrase is certainly not used can be obtained by formally considering the definitions of the terms in its composition.

\section{THEORY\&PRAXIS IN THE EVOLUTION OF HYBRID WARFARE}

\subsection{Short history}

A brief foray into history shows us that hybrid warfare has been present since ancient times, through various forms of expression, in conflicts between states.

\footnotetext{
${ }^{101}$ Mr. Constantin Popa is engineer of tanks and wheeled vehicles, Senior Officer / Colonel in the Logistics Directorate of the Romanian Defense Staff (Head of the Logistics Support Service / Logistics Department).
} 
Thus, the use of elephants (3rd century BC) by Hannibal's army against the Roman army was an element of absolute novelty on the battlefield. The psychological effect of the presence of enormous pachyderms was the real blow against the Roman army, far superior to the military (elephants could be assimilated to today's armor, providing maximum protection, mobility and force of impact).

The Carthaginian approach, by its unconventional nature, can be interpreted as a hybrid tool for waging war. Therefore, it can be appreciated that, since ancient times, actions and operations have been used / carried out with an unconventional, irregular nature or that were not usually part of the rules and customs of war.

Later, in the Middle Ages, the actions of pirates in the service of Queen Elizabeth I of Great Britain, against Spanish ships, were, in fact, hybrid methods of waging war.

In the same logic, of the use of unconventional tools for waging war, we can mention the collaborative actions of George Washington's army with local militias during the American War of Independence, from 1775 to 1783 . Moreover, the contribution of local militias to the effort the war of the 13 colonies that declared independence from the British Crown was substantial, given that the regular U.S. military had only just been established and its operational capability was, for much of the War of Independence, at a high level. quite low.

Another example of the hybrid component of a war is the collaboration of the British regular army with the Spanish army and Spanish guerrilla forces in the fighting against the Napoleonic armies during the "Peninsular War" of 1807-1814.

In the First World War, at least two types of weapons that were used by the German army and that constituted a shock to the Entente can be considered from the category of hybrid arsenal: submarines and toxic gases (mustard gas). Thus, the fear and sentiment of inferiority to the British Naval Forces pushed the German military leadership to approach a more than cautious attitude in engaging the German Imperial Navy's War Fleet in large-scale battles with British enemies. As a result, the attention of the German admirals turned to the impetuous development of the submarine fleet and implicitly to the total submarine warfare, nothing more than a form of "unrestricted" warfare.

An example-rich and well-argued presentation on the use of hybrid methods in conflicts in history can be found in the work of the American military historian Peter R. Mansoor, entitled "Introduction Hybrid Warfare in History". Through this study, the author demonstrates that hybrid warfare has a long history, starting in ancient Greece and being present in many of the conflicts on various meridians. At the same time, the American historian points out that hybrid warfare has evolved substantially, becoming, in the 21 st century, a complex manifestation by combining 
different approaches to war, which essentially reflects strategic cultures, historical legacies, geographical realities and economic means of the protagonists ${ }^{102}$.

Therefore, "hybrid warfare" is developing in multiple areas, being increasingly adopted at the level of some states that base their military doctrines or security strategies on methods and tools unconventional or unusual in the classical sense of war.

\subsection{Fundamental elements of the concept}

If we consider the "hybrid war", as the war of all possibilities or the war without restrictions, we can also establish those who, throughout history, have contributed to the foundation of the concept.

Thus, in "The Art of War", more than 2,500 years ago, Sun Tzu opens horizons for approaching war by other means and tools than those that are strictly military or that include only armed actions. Thus, at least the following citations may be submitted for example:

"He who fights for victory with the sword alone is not a good general."103 Therefore, Sun Tzu expresses with the utmost clarity that a war is waged with other means, and even these are the recipe for success.

Then, with the quote "Attack where the opponent does not expect"104 the great strategist invites to find any opportunity, even too little in the military field, to hit an opponent. Basically, it is not, stricto senso, about a place or a position but about identifying the vulnerabilities of the opponent.

Moreover, Sun Tzu states that "Those who are experts in the art of war subdue the enemy army without a fight." ${ }^{105}$ Or "submission of the army without a fight", even if it seems to be a paradox, actually expresses the value and supreme force of other means and methods of conquest, but which are part of the game of war, battle and confrontation.

And last but not least, the quote "In war the best policy is to conquer the state intact; destroying it is the last resort." 106 It can be deduced that the main effort should not be the military one, on the contrary, this being the last solution. There must be a constant threat of military force, but victory must be achieved by other means and methods.

In an arc over the millennia, we find another famous expression of war or somehow a definition of it. General Carl von Clausewitz, in his famous work "On War", entitled a subchapter with the following phrase: "War is only a continuation

\footnotetext{
102 Peter R. Mansoor, Introduction Hybrid Warfare in History, in Williamson Murray, Peter R. Mansoor, eds., Hybrid Warfare: Fighting Complex Opponents from the Ancient World to the Present, Cambridge University Pres, 2012, https://assets.cambridge.org/97811070/26087/excerpt/9781107026087_excerpt.pdf, , accessed 15.05.2021. ${ }^{103}$ Sun Tzu, Arta războiului, cap. III Strategia ofensivă, pct. 6 pag. 23, Editura Antet XX Press, Regia Autonomă a Imprimeriilor, Imprimeria CORESI București.

${ }^{104}$ Sun Tzu, op.cit., cap. I Evaluări, pct. 26, p. 13.

105 Sun Tzu, op.cit., cap. III Strategia ofensivă, pct. 10, p. 24.

${ }^{106}$ Sun Tzu, op.cit., cap. III Strategia ofensivă, pct. 1, p. 22.
} 
of politics by other means"107. The author develops the content of this title, which became famous over time, in the following form:

"We see, therefore, that war is not a political act, but a real political instrument, a continuation of political relations, their realization by other means"108. With the clear and assumed mention that the quote should not be broken from the overall context of the paper and without entering into the almost philosophical complexity of the meanings and interpretations of the great military theorist's thought, the question can still be asked: What can be understood by "other means" syntagma? And it is clear that the answer does not refer only to strictly military means, but to all the forms, methods and actions that, in a war, can contribute to victory.

Continuing the approach regarding the theorists of the concept of "hybrid war" we will mention the contribution of the two Chinese officers, Colonel Qiao Liang and Colonel Wang Xiangsui, who in the work entitled "Unrestricted War", published in 1999 by PLA Literature and Arts, develops the subject of open thinking in order to discover new ways to fight with any opponents and against any abilities. The two theorists thus state the basic feature of hybrid warfare - war without rules and restrictions.

Chinese authors argue that "unrestricted warfare" means the execution of multiple attacks on the social, economic, political systems of the enemy, which, synchronized or interspersed with attacks specific to an irregular military war will weaken the opponent. It further states that unrestricted war "ignores and transcends the boundaries of the battlefield and what does not represent the battlefield, between what is and what is not a weapon, between military and civilians, between state and non-state actors."109

This theory develops to increase the chances of the weaker party participating in the conflict.

\subsection{Contribution of the Russian School in defining the concept}

Regarding the theorizing of hybrid / unconventional operations among Russian specialists, it can be stated that, over time, since the Second World War, there have been approaches and analyzes of actions and operations that fall into this paradigm.

Thus, the Russian military theorist Evgheni Messner (1891-1974), an officer in the tsarist army who emigrated from Russia after the victory of the Bolshevik forces against the white-guard troops, pointed out that the Bolsheviks

\footnotetext{
${ }^{107}$ Carl von Clausewitz (gen.), On War, BOOK I. ON THE NATURE OF WAR, CHAPTER I. What is war?, para 24. WAR IS A MERE CONTINUATION OF POLICY BY OTHER MEANS, The Project Gutenberg EBook, online https://www.gutenberg.org/files/1946/1946-h/1946-h.htm, accessed 15.05.2021.

${ }^{108}$ Carl von Clausewitz (gen.), op.cit.

${ }^{109}$ Qiao Liang (col.), Wang Xiangsui (col.), "Unrestricted Warfare" - Thoughts on War and Strategy in a Global Era, Part I, Introduction, People s Liberation Army Arts Publishers, February 1999, Summary translation, https://fas.org/nuke/guide/china/doctrine/unresw1.htm, accessed 15.05.2021.
} 
had devised a new type of war, the insurgency" or "insurrectionary war", in order to provoke and possibly defeat the West, without fear of triggering a direct military confrontation ${ }^{110}$.

Describing this type of conflict, the Russian theorist points out the absence of the peace-war dichotomy and a classical front line, while noting the dominance of the psychological component. Evgheni Messner established that this type of conflict has as main attributes: the unconventional and unorthodox character, an ambitious strategic design, planned and executed with professionalism, extended and gradual, based on doctrines of war, but also on nihilistic principles.

The goal of "insurrectionary warfare" is to induce panic in the mind of the enemy, distrust of leaders, their own strengths, opinions, feelings, and demoralization of troops and the population.

After 1991, the works of Evgheni Messner, "Insurgency - the name of the Third World War" and "World Insurrectionary War" began to be studied in Russian military educational institutions, and many of his ideas were included. in the Russian hybrid warfare strategy, developed in 2012 by the Russian General Staff and presented, for the first time, by Valeri Gherasimov, in early 2013, during a meeting at the Academy of Military Sciences.

An important source of inspiration for Valeri Gherasimov is Gheorghi Samoilovich Isserson (1898-1976) - Soviet colonel, professor, one of the authors of the "theory of deep operation". In his work, entitled "New Forms of Combat", published in 1940, he talks about increasing the role of non-military methods of pressure on the enemy, through political, economic and humanitarian instruments and highlights the information component as the main activity in all stages of the conflict. ${ }^{111}$

Beyond the interest of Valeri Gerasimov, in the Russian space of the last years concerns have been identified for the presentation of the perspective on the hybrid war both in the military circles and in the reflection centers, the outlined ideas being found even in the official documents.

\section{CASE STUDY - THE CONFLICT IN UKRAINE}

\subsection{Russia's actions in the conflict in Ukraine}

The phrase "hybrid war" has been widely used in the pages of specialized publications and in the presentations of various concerns, especially after the occupation of the Crimean Peninsula by the Russian Federation in March 2014. What particularly characterized the Russian action in Crimea, apart from the total lack of legitimacy and legality?

\footnotetext{
${ }_{110}$ Nicolescu, Florina Mihaela, Războiul hibrid. Perspectiva conceptuală rusăa, "Intelligence în serviciul tău”, 18 December 2017, https://intelligence.sri.ro/razboiul-hibrid-perspectiva-conceptuala-rusa, accessed 15.05.2021.

${ }^{111}$ Nicolescu, Florina Mihaela, op.cit..
} 
A combination of actions, tools and methods that proved tragic for Ukraine and successful for Russia.

In short, the actions, tools and methods developed and used by Russia for the occupation and subsequent annexation of the Crimean Peninsula consisted of: blocking Ukrainian forces in barracks and disarming them (or disabling them), triggering strong psychological actions of intimidation, blackmail, misinformation and propaganda media, the combined use of own forces and local collaborators, the leadership of forces through an integrated / unified information system, not necessarily hierarchical, but with ensuring a freedom of action for those involved in carrying out missions.

The analysis of the mode of action of the Russian forces involved in the occupation and annexation of the Crimean Peninsula resulted in the following aspects of interest:

a) the operation was planned down to the smallest details so that its development is executed according to the established terms and without any major defect in achieving the tasks and objectives;

b) the development environment was facilitated by the existence in the peninsula of a strong Russian-speaking ethnic component, over 58\% of the population being of Russian ethnicity. It is thus used, according to the so-called "fifth column" hybrid warfare theory;

c) the knowledge and use of the Russian language both by the aggressor forces and by the Ukrainian military, local authorities and the population as a whole;

d) a significant part of the persons involved by the Russian side and who had various responsibilities for the implementation of the plan of occupation and annexation of the Crimean Peninsula were locally known figures. This fact explains, on the one hand the lack of reaction of the members of the other ethnic communities (Ukrainian and Tatar) and on the other hand, the full success of the political action of organizing, leading and executing the annexation (organizing and conducting the referendum, control). the activity of the population, the impeccable functioning of the propaganda apparatus, etc.);

e) a totally diluted will to action and response, even absent, both for the Ukrainian military forces, and especially for the local government authorities. The inaction of the main institutions / elements of state authority was determined by the occupation, in time, of some key positions, by persons of Russian origin who in fact became agents of the Russian espionage offices and acted, at the right time, in strict accordance with the instructions of the Moscow plant, whether it was the FSB, GRU or other Russian structures specializing in intelligence.

However, it remains a mystery the total lack of reaction of the Ukrainian armed forces deployed in Crimea, forces estimated at about 16,000 Ukrainian soldiers, to the actions of taking over the military barracks, means and equipment of combat 
and last but not least taking over the main strategic points. and the headquarters of local government authorities.

It should be mentioned that the actions of taking over the barracks, military equipment, objectives of strategic importance were carried out by "green men" paramilitary forces equipped in uniforms but without the recognition of any army / state, but also by military forces Russian troops deployed on the peninsula, in the military port of Sevastopol, as well as in other military facilities used by the Russians on the basis of agreements agreed with the Ukrainian state. Here can be highlighted the Russian naval units deployed in Crimea, the paratroopers (worth several battalions), as well as special forces units Spetsnaz.

A possible explanation for this situation could be found by revealing the discussions and debates that took place in the National Defense and Security Council on February 28, 2014.

The council, led by then-interim president Aleksandr Turchynov, was convened a week after President Viktor Yanukovych lost power and a day after Russian special operations forces took over/occupied government and local authorities. as well as the strategic objectives of Crimea.

Although interim President Aleksandr Turchynov has expressed a desire to declare a state of war immediately and to react accordingly, ministers and other politicians disagreed.

The politicians present at the meeting of the National Security and Defense Council emphasized, through their positions, that Ukraine cannot wage a war alone and that the West will not give it any help.

The eloquence in the sense of those presented was the intervention in the Council of the Ukrainian Minister of Defense, Ihor Tenyukh. According to Euobserver, he vehemently supported the following:

"We are not prepared for a large-scale war. We need time. We need help. We need a strong reaction from the whole world, from the international community. I will speak openly. We don't have an army today. It was systematically destroyed by Yanukovych and his entourage."112

At the same time, it can be seen that Russia's action in Donbass, following the de facto occupation and de facto and de jure annexation of the Crimean Peninsula, met with a much higher level of resistance from the Ukrainian central and local authorities, both militarily and of political, economic, social and administrative actions.

Although in several areas on the left bank of the Dnieper, the population of Russian origin has a significant share in relation to the total population in that area, the actions of force to take control of these areas (districts / oblast in eastern Ukraine) were successful. quite limited.

\footnotetext{
112 Rettman Andrew, West told Ukraine to abandon Crimeea, document says, "EUOBSERVER", 24 February 2016, https://euobserver.com/foreign/132425, accessed 15.05.2021.
} 
Revolt actions organized by Russian-backed protesters / separatist groups in Dnepropetrovsk, Berdyansk, Kharkov, Slaviansk, Mariupol, but also in other localities were eliminated / controlled by Ukrainian state authorities, with proRussian forces gaining control only on the surface. relatively limited in the Donetsk and Luhansk districts on the eastern border of Ukraine.

It is important to note that for the occupation of the respective territories of Donetsk and Luhansk oblast, Russian-speaking paramilitary forces were heavily supported with heavy weapons (tanks, infantry fighting machines, self-propelled heavy cannons and howitzers, as well as the dreaded Grad projectile launchers). , Smerci and Hurricane), ammunition, fuel, specialized information and communications support.

At the same time were documented by the US and Ukrainian specialized media, the participation of Russian regular military forces in the fighting on Ukrainian territory, during 2014-2015, when the Ukrainian military forces were close to achieving results. decisive against pro-Russian separatist forces.

\subsection{The actions of the Russian Army in the hybrid war in Ukraine}

The Russian military forces participating in the battles on the territory of Ukraine were battalion and even brigade-level tactical groups that were, between August 2014 and March 2015, between 3,500 and 6,500 soldiers, reaching approximately 10,000 troops during the fighting in Debaltseve. ${ }^{113}$

To achieve this level of strong participation, the Russian Ministry of Defense created a rotating system, in which units from all armed armies and from all Russian military districts participated. Usually organized into battalion-level tactical groups, they were usually generated from a single division or brigade and deployed in the center of gravity, where they were used as shock troops alongside less trained separatist forces. ${ }^{114}$ Tactical groups usually consisted of motorized or mechanized infantry, tanks and artillery, occasionally reinforced by specialized units, depending on the missions.

Separatist formations in eastern Ukraine were reinforced with so-called volunteers and supported by Russian military advisers, often with Spetsnaz operators or GRU agents intended, in particular, for conducting reconnaissance and sabotage missions.

In addition to the maneuvering units, a substantial number of Russian troops were concentrated and stationed on the Russian side of the border, in order to provide logistical support, training and to carry out cross-border artillery strikes in support of Russian armed forces operations on Ukrainian territory. and the separatists in Donbass.

\footnotetext{
113 Noorman Randy, The Battle of Debaltseve: a Hybrid Army in a Classic Battle of Encirclement, "SMALL WARS JOURNAL", 17.07.2020, online https://smallwarsjournal.com/jrnl/art/battle-debaltseve-hybrid-army-classicbattle-encirclement, accessed 15.05.2021.

${ }^{114}$ Noorman Randy, op.cit..
} 
In addition to training and advising separatist militias in Lugansk and Donetsk, Russia has also provided a large number of specialized military personnel to operate complex weapons systems (battlefield surveillance radars, counter-battery radars for locating Ukrainian artillery batteries, UAVs for research, reconnaissance, battlefield observation) ${ }^{115}$.

Moreover, the conduct of military operations was and is carried out by a command composed of Russian military personnel, which is part of the assets of the Russian Army.

At the same time, a significant and varied number of electronic warfare (EW) systems were used, a specific aspect of Russian military operations.

Electronic warfare equipment was used in combination with UAVs in order to block Ukrainian communications, as well as to detect, identify, target and find targets for accurate artillery fire during combat operations.

Russia has used innovative methods to increase the fighting capabilities of separatist forces, while continuously denying Russian military involvement, although this denial has seen a sharp downward trend in credibility among international public opinion.

First of all, it ensured the increase in the number of available combatants, mainly through the integration of highly trained Russian military personnel and the transfer of sophisticated weapon systems.

Second, it has effectively integrated state-of-the-art technologies into regular tactical activities.

At the same time, it aimed to apply traditional Russian military features and tactics that have ensured the success of military operations over time, such as the massive use of artillery fire.

The effective entry into battle of Russian units led to the cessation of the offensive of the Ukrainian military forces and their pushing to the west of the two districts - Donetsk and Luhansk. In the end, the situation stabilized on the current contact alignment.

Russian military forces have caused considerable losses to Ukrainian forces, with defeats suffered by the Ukrainian army at Debaltseve and Donetsk Airport being caused by the direct and destructive intervention of compact Russian military formations.

In the fighting on the territory of Ukraine, Russia has created and displayed a hybrid army, using a variety of methods and tools to operationalize and support separatist forces.

From an operational point of view, in Debaltseve the Russian army carried out a classic siege battle in which a significant Ukrainian force was imprisoned (between 5,000 and 8,000 Ukrainian soldiers were caught in the Debaltseve encirclement). ${ }^{116}$

\footnotetext{
115 Ibidem

116 Ibidem.
} 


\subsection{Russia's objectives in the conflict with Ukraine}

However, there are some question marks compared to the ones presented.

The fact that the Russian Federation has planned in the smallest details and details, on multiple levels of approach and using unconventional methods and tools in preparing and carrying out the aggression against Ukraine is clear and unquestionable. The application of hybrid methods and actions was not something done in a hurry, in a hurry, it was not a momentary improvisation. It was the implementation of an entire theory of waging war with other "weapons" and "means", a theory that was carefully and patiently developed, being then put into practice by perfectly planned, coordinated and executed actions.

And now comes the question. Why did the Russian Federation choose to apply this type of war to Ukraine?

It is known that hybrid actions are the prerogative of the weakest in a conflict between two parties.

The conflicts between Israel and the fundamentalist organizations Hamas and Hezbollah are perhaps the most eloquent examples of the manifestation of hybrid warfare methods, in this sense being appreciated the actions of the two organizations (terrorist attacks, random missile attacks, strong anti-Israeli propaganda in all Arab media and beyond), organizing violent street demonstrations both in the West Bank and Gaza but also in Israeli towns with Arab population, etc.).

To decrypt the Kremlin leadership's option to apply the methods of hybrid warfare against Ukraine, we can start from the following assessment.

In any conflict, the aggressor, because, in general, one of the parties, regardless of the causes, can be considered an aggressor, establishes the objectives he seeks to achieve / fulfill.

Usually, maximum, minimum objectives / targets are set, but also mandatory objectives / targets.

Compulsory objective means that objective which represents the main purpose of the action, for the achievement / fulfillment of which the majority of resources are destined and which represents the main line of effort.

In addition to the mandatory target, the minimum and maximum targets are set, in the sense that in addition to the achievement of the main target, the other targets proposed for achievement between some minimum and maximum limits are added.

Returning to Russia's aggression against Ukraine, we can consider the following hypothesis regarding the content of the action planning directive:

- main objective - occupation and annexation of Crimea;

- minimum objectives - the establishment of a solid "bridgehead" on Ukrainian territory, in the Donetsk and Lugansk districts, the size of which would allow at least the creation of separatist territorial entities that could 
withstand Ukrainian forces over time and ensure the permanence of a conflict zone on the territory of Ukraine.

In addition, in the situation of perpetuating the state of conflict, Russia ensures the maintenance of a buffer state, namely Ukraine, against the eastern borders of NATO. Moreover, it nullifies Ukraine's aspirations and chances of joining the North Atlantic Alliance.

- maximum objectives - "raising the fighting" of the entire Russian-speaking population on the left bank of the Dnieper (understood here from all districts on the left bank of the Dnieper where the Russian population has a significant share of over $30 \%$ of the population), declaration of independence of these districts / oblasts and their annexation to Russia. Thus, the Novorossiya project would have materialized, respectively the revival of what was the Novorossiya Governorate in the Tsarist Empire. In a small recourse to history, we will mention that the Novorossiya Governorate was founded in 1764 by Empress Catherine II, whose name it originally bore.

Because it was at that time an expansion of the Tsarist Empire, Catherine II changed the name of the province to Novorossiya (New Russia) to be in tune with Western European fashion in which the powers of the time christened their new conquests territories with names that kept the name of the mother state: New England, New France, New Spain.

It is important to note that, through territorial expansion, the Novorossiya Governorate has come to overlap, practically, on the current territory of Ukraine.

In support of the viability of the hypothesis that the ultimate objective was the restoration of the province of Novorossiya and its return to Russian sovereignty, at least two arguments based on actual facts can be put forward:

a) In an interview on April 17, 2014, shortly after the occupation and annexation of Crimea, the President of the Russian Federation, Vladimir Putin, stated that the districts of Kharkov, Luhansk, Donetsk, Kherson, Mykolaiv and Odessa were part of Novorossiya;

b) In May 2014, the self-proclaimed Donetsk and Luhansk People's Republics announced the establishment of the Novorossiya Confederation and declared their intention to expand into southern Ukraine. The political project was supported for a period of 1 year, until May 20, 2015, when the leaders of the selfproclaimed People's Republics Donetsk and Luhansk announced its freezing.

Following the hypothesis regarding the objectives set in the Kremlin for the "case" Ukraine, we consider the following statements to be important:

1. The goal of bringing Crimea back into the Russian Federation has been set at least since Vladimir Putin took power in the Kremlin.

President Putin is a representative example of the Russian national consciousness expressed in terms of the exceptionality of the Russian nation, the preservation of the Russian spirit of Russian history, tradition, power and 
significance, the maintenance of territoriality at all costs (philosophy of Russia's gigantic surface area expansion and not cession of territories, regardless of the historical context).

The Crimean Peninsula, incorporated into the Tsarist Empire during the reign of Empress Catherine II, has a special historical significance for the Russians, in their entirety as a people. Thus, in the Crimean War (1853-1856), in the First World War as well as in the Second World War, the Crimean Peninsula was occupied by attacking forces, the loss, even temporary, of this territory, having a very strong psychological and emotional effect on the Russians.

The Crimean Peninsula is also of great importance to the Russian oligarchy, for which it is a pearl of tourism and relaxation (many Russian potentates own holiday properties in the Crimean Peninsula).

Last but not least, the special strategic role of the Crimean Peninsula should be emphasized (this was also the main reason for the occupation of the peninsula in the three wars mentioned above), this territory being the "unsinkable aircraft carrier" which gives an undeniable military advantage for Russia. Thus, Crimea was and became, after the occupation and annexation by Russia, the main airnaval base of Russia in the Black Sea, a place from which the Russians can project their forces to the Mediterranean.

2. Lack of feasibility of a maximum target to establish full control of Ukraine. Although this option, certainly analyzed in the Kremlin's laboratories, could be considered as a possibility with chances of success, it was at least postponed, if not abandoned. In support of this hypothesis, the following considerations can be highlighted:

a) achieving the objective by classical military action:

- even if the Ukrainian army had an extremely difficult operational situation, a total war for the occupation of Ukraine would have led to considerable losses for the Russian army, which was difficult for the Russians to justify, even if a huge propaganda apparatus was used to justify the action;

- for the military occupation of the entire Ukrainian territory, the Russian armed forces would have come dangerously close to the borders of NATO states, which would have led to a reaction of mobilization and movement to the borders of the armed forces of these states, and (almost certainly) of allied military forces. It must be borne in mind that there was no argument to show with certainty that Russian military forces would stop at the borders of Ukraine's neighboring states;

- the international reaction would probably have been much stronger than that recorded in relation to the course of action taken by the Kremlin in the crisis in Ukraine. In this context, there is the possibility, with a very high probability of being achieved, of applying particularly harsh economic and political sanctions that would have severely affected the Russian economy, which, even under normal conditions, is not performing well; 
- the credibility of the Russian state in relation to other states, especially at European and transatlantic level, would have collapsed. The result would have been a real and strong long-term international political isolation;

- the de facto occupation of Ukraine would have placed an additional burden on the Russian economy, requiring substantial resources to be maintained for the functioning of the institutions and society in the occupied territory;

- the existence of strong Russo-phobic accents, especially in western Ukraine (both religiously from the Catholic population, quite large in this part of Ukraine, and of the Ukrainian population in general) would have created the conditions for manifesting hostile attitudes that are difficult to controlled;

b) achieving the goal by using the methods of hybrid warfare

- the action of the "green men" would have had very little chance of success on the scale of the entire Ukrainian territory. As proof, it did not work even in the area of the oblast on the left bank of the Dnieper, although there were actions of these forces, especially in the south-eastern part of Ukraine, but they were not successful;

- the population of western Ukraine was, at least in the context of the Maidan Movement, totally against Russia and overwhelmingly pro-Western;

- a large part of the methods of hybrid warfare (propaganda, undermining state institutions, undermining the economy, information warfare) become effective and usually yield long-term results, especially as the objectives are more ambitious;

- the likelihood of a civil war on the entire Ukrainian territory would be particularly high, and its consequences, even if it led to the collapse of the state, would certainly have had major negative effects on Russia and its interests;

- the size of the objective, respectively the taking over of the control of the whole state, would have caused major difficulties in controlling the evolution of the situation, and a possible negative evolution in relation to the aggressor's intentions would have increased the involvement and the probability of degenerating;

- the hybrid actions would have become much clearer and more visible than those carried out in Crimea and eastern Ukraine, which would have led to much stronger international reactions and would have led to much harsher political and economic sanctions;

- a possible failure would have led to the loss of Russian confidence in Putin's leadership and would have severely eroded his position in the Kremlin ruling class; 
- the loss of confidence would have manifested itself at the level of the former states of the composition of the Soviet Union that revolve around the orbit of Moscow.

\section{PROS AND CONS FOR THE HYBRID WARFARE}

\subsection{Advantages of the Hybrid Warfare}

Returning to the search for the answer that determined Moscow's option for a hybrid aggression to the detriment of a classic military action, in view and considering the hypothesis of the content of the planning directive as presented above we will evaluate and balance the arguments that were probably taken in consideration of the gray eminences of the Kremlin for choosing the optimal course of action.

Therefore, we will state the advantages and disadvantages of hybrid warfare compared to conventional warfare, also supporting the fact that this analysis benefits from knowing the result, in the sense that it is done post-factum.

To begin with, it must be borne in mind that, depending on the evolution of the situation, the builders of the scenario kept both options open or rather thought that the launch and execution of the hybrid operation could be supported, if necessary, by the purely military option.

At the same time, it can be stated with certainty that the Kremlin analysts and planners did not establish from the beginning that there may be two working options but identified the problem, set out in detail the elements of the existing situation or possibly develop, set the purpose and objectives. and detailed the actions needed to fulfill them, respectively developed the possible scenarios.

Finally, they analyzed the probability of success of each action.

Following the logic of the elements presented above, in support of the hybrid action approach, the following advantages can be identified quite easily:

a) the hybrid actions have an innovative character; they allow developments in any field in which vulnerabilities of the opponent are identified and own possibilities / resources of action;

b) the depth of the act of aggression depends more on the weakness of the opponent and less on his own ability to allocate resources;

c) aggressive actions on multiple levels, allow both a deeper penetration and a rapid retreat in case of encountering a strong resistance in the considered field;

d) hybrid actions can be prepared and triggered long enough before the occurrence of the open conflict state. In support of this argument, we will note the speed of taking over the Crimean barracks and public institutions, as well as the speed and effectiveness of organizing and validating the referendum on Russia;

e) even if they became visible shortly after the overthrow of power in Kiev and the aggressor was identified as Russia, the hybrid actions allow the use of a 
strong communication strategy of denying involvement (which the Russian authorities did).

The perversion of the truth and / or the interpretation of actions / situations can be taken very far. The evidence is the quantities of weapons, combat equipment (ground) and ammunition sent across the border to the aid of separatist forces. Their origin has long been denied by the Russian authorities, their basic explanation being that Ukraine also owns such equipment and the separatists armed themselves from the Ukrainian army depots to defend themselves against "fascists who took power".

Moreover, even after being taken prisoner, proved to be part of the Russian Army, President Putin nonchalantly stated that yes, there is this possibility, but the military is fighting in Ukraine as ordinary Russian citizens to defend the blood brothers and they do not represent Russian armed forces. In addition, at the time of their detention on Ukrainian territory, they were on leave or on leave (ie they were in their spare time) and took part in combat operations on their own responsibility.

However, in this context, it is interesting to note that, although they participated with combat units consisting of Russian soldiers or they formed the hard cores of structures combined with separatist forces, Russia did not use aviation on Ukrainian territory. The application lies in the difficulty of concealing the origin of the aircraft;

f) hybrid actions, especially those based on information warfare, fake-news, propaganda, infiltration into institutions, key points in the economy (when possible, and in the case of Ukraine the infiltration ground was extremely favorable and permissive, including in the highest spheres of power, the army, the secret services, etc.) ensure the division of the population and the decrease of its morale and will to fight, the sharp decrease of confidence in the institutions and strength of the state, the enthronement of fear, etc.;

g) a major advantage of adopting hybrid methods is to ensure the possibility of withdrawal in case of failure, without assuming it. Failure to achieve the objective is not obvious and can easily be avoided or, if necessary, justified. This aspect is particularly important for one's own public opinion, on the support of which any political leader relies.

Thus, for the Russian leadership it was quite simple to induce to the Russian people the idea of obtaining a great victory (at least only by annexing Crimea and fixing a "bridgehead" in the Donbass), because the failure to achieve the ultimate goal of re-establishing Novorossiya Province (of course integrated into the Russian Federation) provided that:

- the hybrid actions took place "covered", the results obtained being clear and transparent, and the failures did not exist because the actions, to a large extent, were not visible; 
- Even if the public expected more, knowing or intuiting that Russia supports the separatist forces, the explanation for the failure was simply guilty being the supporters who were unable or unwilling to value Russian support.

h) hybrid actions, especially in the situation when state entities are involved in the conflict, are predominantly offensive. Considering that if we consider the "offensive" strictly from a military point of view, we can say that the adoption of this form of combat is made in the situation of achieving, at least on the main offensive direction, a sufficient superiority of forces and means at least in theory, the conditions for success. Thus, for the hybrid action it is not so important how much resources are allocated but how they are prepared and how "they are put into battle"; in the present case it has allowed Russia to be able to create a vague, uninvolved image or one whose involvement is presumed, suspected but not proven;

j) hybrid actions can be used much more easily by an autocratic state. In the present case for Russia, led authoritatively by Vladimir Putin, there were no voices asking what the costs of such actions were, what Russia's involvement in the conflict was, why Russian soldiers were killed in the Donbass, how much it cost to support separatist forces and function. the two self-proclaimed people's republics of Donetsk and Luhansk, etc. Along the same lines, China, Iran and, why not, Turkey are in line with the realization of a substantial potential for hybrid actions.

\subsection{Limitations and disadvantages of the Hybrid Warfare}

Hybrid actions, normally, also have disadvantages.

Thus, in the specific case of the hybrid actions of Russia against Ukraine, the following disadvantages of this approach can be highlighted:

a) the need for a thorough, detailed and very precise preparation of the actions, as well as the very high level of expertise of those involved in the implementation of the action plans;

b) identification of ways and means of ensuring the masking, concealment and concealment of actions, both against the opposing party and against third state entities;

c) a long period of time for obtaining the results, which requires the preparation and development of actions long before the moment when the conflict is foreseen;

d) a special effort for the integration, management and follow-up of actions;

e) the long time necessary for the training of specialists in carrying out such actions;

f) the need to ensure maximum flexibility in conducting hybrid actions in order to identify opportunities, risks, limit failures, achieve rapid changes in the situation, etc .; 
It follows, therefore, that hybrid warfare, even if it can be appreciated as the weapon of the "poor", is experiencing increasing development and application and is beginning to become the main form of action of some state entities, especially the authoritarian ones.

\section{CONCLUSIONS}

Hybrid warfare is increasingly a form of conflict today, regardless of its protagonists. The period of punctual or circumstantial application of methods specific to hybrid warfare has been exceeded. At present, the methods of hybrid warfare have become the main elements used in an aggression. In addition, the diversity of methods, their wide spectrum of use and the multitude of areas in which they manifest themselves, as well as the effects they generate, make hybrid warfare the most complex form of aggression.

An important feature of hybrid actions is that they tend to become a permanent and widespread presence, both at the state and non-state entities level.

Actions or rather hybrid aggressions are constantly diversified as a spectrum of manifestation and take place right outside the conflict areas / spaces. Moreover, through the actions from the informational, propagandistic and cyber spectrum, these actions transcend the characteristic of territorial proximity, manifesting itself on the whole world map.

Given the innovative nature of these aggressions, it is becoming increasingly difficult to control them, discover areas of manifestation and identify countermeasures.

The hybrid war waged by Russia in Ukraine continues even after 7 years since the occupation and annexation of Crimea and has been a very good school for the development and refinement of methods and tools for Russian specialized services that the Ukrainian conflict.

In the conflict in Ukraine, it is possible that Russia did not achieve the proposed maximum targets but achieved its mandatory targets and at least the minimum ones. In addition, by continuing hybrid aggression in Ukraine, it is on track to achieve new goals, which this time are much more ambitious and go beyond the current area of the conflict zone.

In the same framework of development, refinement and use of hybrid aggression methods, China was also involved, whose potential can be appreciated, without fear of error, as the most developed in this field, given the available resources, economic strength and military and last but not least the undemocratic character of the state leadership.

So, hybrid warfare cannot be seen just as a complex, integrated representation of classical warfare. It is an independent, highly disruptive and diverse form of total conflict. 


\section{BIBLIOGRAPHY}

- Von Clausewitz C. (gen.), On War, BOOK I. ON THE NATURE OF WAR, CHAPTER I. What is War? para 24. WAR IS A MERE CONTINUATION OF POLICY BY OTHER MEANS, The Project Gutenberg EBook, o,,Unrestricted Warfare" - Thoughts on War and Strategy in a Global Era,nline https://www.gutenberg.org/files/1946/1946-h/1946-h.htm

- Liang Q. (col.), Xiangsui W.(col.), Part I, Introduction, Published by People s Liberation Army Arts Publishers, February 1999, Summary translation, online https://fas.org/nuke/guide/china/doctrine/unresw1.htm

- Mansoor P.R., Introduction Hybrid Warfare in History, in Williamson Murray, Peter R. Mansoor, eds., Hybrid Warfare: Fighting Complex Opponents from the Ancient World to the Present, Cambridge University Pres, 2012, online https://assets.cambridge.org/97811070/26087/excerpt/9781107026087_excerpt. pdf

- Nicolescu F.M., Războiul hibrid. Perspectiva conceptuală rusăa, "Intelligence în serviciul tău", 18 decembrie 2017, online https://intelligence.sri.ro/ razboiul-hibrid-perspectiva-conceptuala-rusa

- Noorman R., The Battle of Debaltseve: a Hybrid Army in a Classic Battle of Encirclement, "SMALL WARS JOURNAL", 17.07.2020, https://smallwarsjournal.com/jrnl/art/battle-debaltseve-hybrid-army-classicbattle-encirclement

- Rettman A., West told Ukraine to abandon Crimeea, document says, "EUOBSERVER", 24 februarie 2016, https://euobserver.com/ foreign/ 132425

- Sun Tzu, Arta războiului, Editura Antet XX Press, Regia Autonomă a Imprimeriilor, Imprimeria CORESI București. 